\title{
Site Specific Dance: Relationship Between Body and Space
}

\author{
Eko Supendi* \\ University Center of Excellent on Choreographic and Artistic Research \\ Institut Seni Indonesia Surakarta, Indonesia \\ Satriana Didiek Isnanta \\ Institut Seni Indonesia Surakarta, Indonesia
}

The research is supported by Institutional Directorate of the Ministry of Education and Culture of the Republic of Indonesia

\section{Abstract}

The art of dance has experienced tremendous development. Now, dance is no longer in the realm of fairies, but has entered the center of modern civilization, from pockets of tradition shifting to pockets of industry and academia. This cannot be separated from the role of academic dancers who conduct research, both creation studies and scientific studies. Dance has become a laboratory object in the studios of art academics in Indonesia and various parts of the world, so that laboratories and dance studios have sprung up in various places in Indonesia. Dance is now seen as not only cultivating the soul, dance is no longer limited to aesthetic beauty that is visible to the eye. However, dance has explored other art worlds, such as theater and fine arts.It is now difficult to distinguish between dance and theater presentations. This phenomenon is often the trend of individual artists. Art observers call this phenomenon a contemporary phenomenon. Contemporary phenomena continue to develop in artists and academic circles. In addition to being critical of the social issues that surround it, contemporary art is also critical of its own art. The contemporary spirit does not only break the barriers of one art discipline, but also across art disciplines. Almost all dance elements are explored and developed, one of which is site specific dance. A contemporary dance genre that focuses on creating dance works using special places. This research used artistic research methods, in which the researcher is also the creator of site specific dance works.

Keywords: dance, site specific, space, body, time.

DOI: $10.7176 / \mathrm{ADS} / 97-02$

Publication date: December $31^{\text {st }} 2021$

\section{Introduction}

Dance is one of Indonesia's cultural heritages, which must be preserved and developed in accordance with the development of its society. The art of dance according to Sumandiyo Hadi (2007: 13) is the concept of aesthetic human expression which is an inseparable part of human life in a meaningful society, or in other words dance is created because the imagination of human thought is interdependent with society as a social system.

In general, a dance art certainly has a form. The performance form can be 'Forms of performances performed individually and the form of performances communally or in groups' (Sumaryono, 2007: 4). In essence, communal dance will relate to the supporting community as a facilitator in the show. One expert stated that communal dance is 'An event of dance performances involving large society which is generally a cultural heritage of the past' (Dibia et al, 2006: 1). This is evidenced by the characteristics of communal dance, namely 'the dancers consist of more than one person or danced by many people, it is performed spontaneously or planned, and display a sense of solidarity and familiarity' (Dibia et al, 2006: 57-63).

Dance can not be separated from movements, both regular and irregular movements, movements that have meaning or have no meaning. In a dance, the presentation structure is something to pay attention to, so that the performance of a dance is clear and orderly. In addition, the structure of the dance presentation will make it easier for the audience to judge and make it easier to distinguish the types of movements in a dance.

The presentation structure in dance explains and identifies a dance performance, starting from the beginning, middle to the end of the show. As stated by a dance expert that the structure in a dance, namely 'the occurrence of the beginning, progression and completion of which each part the dance structure has a beginning, middle and end which is required in the needs of the content of the dance itself' (Hadi, 2003: 82).

Over time, the art of dance has experienced extraordinary developments. Now, dance is no longer in the realm of fairies, but has entered the center of modern civilization, from pockets of tradition shifting to pockets of industry and academia.

This cannot be separated from the role of academic dancers who conduct research, both creation studies and scientific studies. Dance has become a laboratory object in the studios of art academics in Indonesia and various parts of the world, so that dance laboratories and studios have sprung up in various places in Indonesia.

Dance is currently seen as not only cultivating the soul, dance is no longer limited to visible aesthetic beauty, but dance has explored other worlds of art, such as theater and fine arts. Dance presentations are often 
found in a festival or performance that seems to adopt other artistic concepts or idioms (Indrayuda, 2010: 65).

It is now difficult to distinguish between dance and theater presentations. This phenomenon is often the trend of individual artists. Art observers call this phenomenon a contemporary phenomenon. Contemporary phenomena continue to develop in artists and academic circles. The concept of contemporary dance works tends to be actual and gives the choreographer the freedom to express himself, although it tends to break the established rules of dance concepts, both traditionally and scientifically (Indrayuda, 2010: 64).

In addition to being critical of the social issues that surround it, contemporary art is also critical of its own art. The contemporary spirit does not only break the barriers of one art discipline, but also across art disciplines. The spirit of the post modern which has encouraged the formation of the contemporary art genre has penetrated all over the world and to all art disciplines, including dance art. Breaking is not only in the flow of presentation, exploration of the body, but also exploration of space. Dance is not only performed on conventional stages but has spread to unconventional spaces, such as on the road, on the beach, or on the river.

This last trend is the focus of this research. Site specific dance is important to research because the creation model is certainly different from the dance creation model that is held on a conventional stage. This research is important in finding a model for creating site specific dance works, as well as enriching learning materials. Art institutions must continue to develop to capture art phenomena that exist outside the campus. The learning material must continue to develop following the existing ones, reading phenomena and being able to explain these phenomena scientifically.

\section{Methodology}

This work creation study method used artistic research methods. The methodological assumption in artistic research is based on the belief that: (1) art research is carried out in the process of forming a work of art (Smith and Dean, 2009: 3 in Guntur, 2016: 5); (2) practice is a mode of investigation that is used to create basic evidence against something that has been demonstrated or found (Pedgley, 2007: 463).

Art-based research is a form of qualitative research that examines humans who use the premises, procedures and principles of art. This research is determined by the presence of aesthetic qualities (or design elements) both in the investigation process and in the research text. Therefore, art-based research differs in several ways from traditional forms of research as those in the social sciences. Art-based research differs from scientific research both in the process in which research is carried out and in the way in which research data is presented (Given, 2008: 29).

In all traditions of good qualitative research methodology, art-based research is seen as having soft concepts and methods. Art-based research allows researchers to use perspective and engage in developing sensitivity in art over time in an effort to generate and present data. This allows us to appreciate art in and of itself as a way of representing an understanding of human life. This can include the creation of text, objects, images and artifacts that cannot be distinguished from the artwork created, such as the exploration of ideas, themes and issues that question us, as a way of theorizing about the world (Thompson, 2006: 3).

Therefore, the artistic research stage which aims to study the creation of this work is designed as art-based research with the following stages: (1) exploration of ideas, themes and issues, (2) artistic creation, and (3) materialization of works.

\section{Results}

Eko Supriyanto, Timbul Haryono, R. M. Soedarsono, Sal Murgiyanto, "Four Indonesian Contemporary Dance Choreographers for the Period of 1990-2008," in the Panggung journal Vol. 24 No. 4, December 2014, discussed four choreographers, in opening the discourse of the bodily process of dancers in Indonesia. The four choreographers, Martinus Miroto, Mugiyono Kasido, Hartati, and Jecko Siompo, showed how the complexity of their bodily processes is different from dancers and choreographers in general, especially from outside Indonesia. They provided detailed experiences about disciplining their bodies to achieve an achievement and excellence. With the complexity of discipline and bodily training, the four dancers and choreographers confirmed how the process of achieving and developing the body lies in several important processes: Training. This scientific article has the same research theme, namely contemporary dance but has a different focus of study. This scientific article discusses the body more, while the research that is being carried out is related to the relationship between the body and space in the process of creating site specific dance.

R.Aj. Siti Nurchaerani Kusumastuti, "The Development of Choreography in Indonesia: A Study of Contemporary Dance Works at the Jakarta Arts Center-Taman Ismail Marzuki 1968-1987," in the dissertation of the Doctoral Program of the Faculty of Humanities, Historical Studies Program, 2016, discussed the significant developments of choreography in Indonesia, including contemporary dance works, occurred since the establishment of the Jakarta Arts Center - Taman Ismail Marzuki (PKJ-TIM) in 1968 - 1987.

According to the results of the dissertation, in Indonesia, in terms of the history of its creation, new dance works developed from traditional, modern, and contemporary tend to start from existing works. Furthermore, 
following the artistic ideas or ideals of the artist, the existing works are processed into newness with all their peculiarities, even traces of old works can be completely invisible. Tracing back, dance artists were motivated to create novelty in dance works which was encouraged by the cultural policies of President Soekarno (1950-1959), which outlined Indonesianness which also applies to arts, including dance.

The desertation of R.Aj. Siti Nurchaerani Kusumastuti discussed the development of contemporary dance in Indonesia which is supported by its supporting agents. Her research focused more on how agents in the social arts field was able to play an active role in the development of contemporary dance in Indonesia, especially at the Jakarta Arts Center-Taman Ismail Marzuki. Of course this article is very different from the focus of future research which focuses on site specific dance. This desertation is used as a reference that needs to be reviewed because it is to find traces of the development of contemporary dance in Indonesia.

Indrayuda, "The Phenomenon of Contemporary Dance in the Dance Work of Sendratasik Students UNP and STSI Padang Panjang," in the Journal of Education and Culture, Vol. 16, Number 1, January 2010. This article discussed the phenomenon of contemporary dance work by Sendratasik students UNP and STSI Padang Panjang in their final project. This research focused on the phenomenon of the tendency of students to create contemporary dance works. This article indirectly proved how contemporary dance has entered the campus environment. There is a process of handling and enriching learning in the campus environment such as the purpose of research to be carried out. The difference is in the focus of the study which is more on site specific dance.

Tim Edensor, Caitlan Bowdler, 2015, "Site-specific dance: revealing and contesting the ludic qualities, everyday rhythms, and embodied habits of place," in the journal of Environment and Planning, volume 47, pages 709-726. This article explored how contemporary dance, site specific dance, can change the meaning, behavior and feelings of urban space. The potential for playfulness, spontaneity, and the absence of the use of standard choreography clashed with the sensuality of urban corners.

Victoria Hunter, "Embodying the Site: the Here and Now in Site-Specific Dance Performance," Cambridge university press, 2005. This article explored the concept of "here and now" in the creation of site specific dance performance arts, the relationship between space and the creative process of performances in site specific dance works. It shows what kind of natural relationship between the space/locus, choreographer, performer, appearance/performance with the audience is. This article is very helpful for researchers in compiling a method for creating site specific dance works.

Melanie Kloetzel, "Site Dance: Choreographers and the Lure of Alternative Spaces," in academia. edu, 2015. This article discussed the tendency of site specific dance to become increasingly popular, where many innovative works of choreographers leave conventional stages/traditional performance spaces to other places. More and more shows are popping up in skyscrapers, on aisles, on trains, on the deck of aircraft carriers, and on a myriad of other unexpected locations around the world. This article explored the work choreographers create for nontraditional performance spaces and the thinking behind their creative choices. This article is interesting, from its lengthy description it has become one of the research references entitled "The Method of Creating Site Specific Dance Works".

Based on the above literature review, it can be concluded that: (1) the history of the creation of modern or contemporary performing arts in Indonesia still refers to traditional art or the source of ideas is taken from preexisting traditional arts, and (2) the development of contemporary art in Indonesia has attracted the attention of young dancers (especially those studying academically). Many contemporary dance works are created on campus. Therefore, contemporary art must be given space in the learning curriculum on campus. In addition, (3) Contemporary art (in general) has the character of deconstructing standardized traditional and modern art conventions, one of which is the emergence of the site specific dance genre. A performing arts genre that does not use conventional staging stages. (4) Presentation/staging site specific dance requires a special place and space, there is an attachment between space, time and body. Therefore, one aspect of the success of a site specific dance performance is the dancer's knowledge of the relationship between body and space, related to bodily knowledge and intelligence in reading the locus and presentation space.

Site specific dance characters have the potential to be playful, spontaneous, and there is no use of standard choreography that is collided with certain spaces. Presentation/staging of site specific dance requires a special place and space. There is an attachment between space, time and body. Therefore, one aspect of the success of a site specific dance performance is the dancer's knowledge of the relationship between body and space, related to bodily knowledge and intelligence in reading the locus and presentation space. Site specific dance is closer to performance art that develops in fine arts than conventional dance.

Dance, according to Derek McCormack (2008, page 1824), is "a mode of popular cultural expression concerned with the experience and manipulation of space at a range of scales and degrees of complexity", and involves thinking "with and through the spaces of which these bodies are generative" (page 1831). Unlike the traditional proscenium setting, where dance takes place within a framed, bounded space and there is a clear separation between performer and audience, site-specific dance occurs in highly diverse locations at which 
topographies, fixtures, buildings, other humans and nonhumans, and a host of other affordances inspire choreographers and are integral to performance. According to Karen Barbour and Alex Hitchmough, sitespecific dance.

"produces a relationship between site, performers and audiences in which the embodied, emotional and sensory experiences of those present are engaged with the design, organic and structural features, as well as the social and cultural histories of the site" (2013, page 5).

While site-specific dance can offer up alternative meanings of urban space, ranging from the fantastical to the practical, it is crucial to emphasise that, as an embodied practice, dance is not purely conceived as concerned with meaning (Enderzon, 2015:724). Elizabeth Grosz emphasizes the relationship between bodies and the city; the latter "is made and made over into the simulacrum of the body, and the body, in its turn, is transformed, 'citified', urbanized" (1998, page 43).

This case of the study on the creation of site specific dance artworks was presented in the Solopos office lobby, a print media office in Surakarta. Therefore, the site specific dance works were created with a theme related to the world of the media industry from upstream to downstream. This includes the medium, namely newspaper. Thus, at the initial stage, the study conducted was to understand mass media and paper.

\subsection{Exploration of Ideas}

Reading the history of paper is like reading the history of human civilization. The explosion of print reproduction began in the 15th century with the creation of printing equipment by Johannes Gutenberg and grew rapidly along with the development of the print industry and mass media. In the information age, the mass media have become a major force for the dissemination of news, knowledge and at the same time become one of the pillars of democracy. When the global public's awareness of environmental issues strengthens, the use of paper media is in the spotlight, including in Indonesia. One tree trunk, when processed into pulp and paper, only becomes 16 reams.

About $70 \%$ of land in Indonesia is state forest area. Indonesia's forests function as the world's lungs and are considered to have significant influence on the world's climate. Apart from being a source of the world's biodiversity, Indonesia's forests have become a concern to maintain their existence. As time goes by, Indonesia's forests are getting lost, the forests that were once rich are now disappearing. According to the Forest Watch Indonesia report 2018, in 2013 Indonesia lost \pm 1.1 million hectares of natural forest. This means that every minute three football fields are lost. Indonesia experiences massive deforestation. In the 2005-2015 period, Indonesia lost 7 percent of its forests (or a total of 1.4 million hectares).

Based on data from the National Forest Monitoring System (SIMONTANA) released in early 2019, it was revealed that deforestation in 2014-2015 was 1.09 million ha. This number then decreased to 0.63 million ha in the 2015-2016 period, and again fell to 0.48 million ha in the 2016-2017 period.

In the forestry science perspective, deforestation is interpreted as a situation of loss of forest cover and its attributes which have implications for the loss of structure and function of the forest itself. This meaning is reinforced by the definition of deforestation as outlined in the Regulation of the Minister of Forestry of the Republic of Indonesia No. P.30/MenhutII/2009 concerning Procedures for Reducing Emissions from Deforestation and Forest Degradation (REDD), which clearly states that deforestation is a permanent change from forested areas to non-forested areas caused by human activities.

To tackle deforestation, the government through the Regulation of the Minister of Environment and Forestry Number: P. 12/Menlhk-II/2015 concerning Industrial Plantation Forest Development. Industrial Plantation Forest (HTI) is a forest that produces plants by applying forestry cultivation to meet industrial raw materials.

HTI is a large-scale monoculture timber plantation that is planted and harvested for pulp and paper pulp production. Trees such as Eucalyptus and Acacia are planted beyond natural productivity limits, with high growth rates and a high tolerance for degraded land. The wood produced from these plantations is used extensively for fuel and in construction and for the production of paper and fabrics such as rayon.

Unfortunately, HTI is actually one of the main causes of deforestation where primary tropical rainforests are replaced by monoculture forests of Eucalyptus and Acacia. These major changes in land use have an impact on environmental and social conditions. The development of large-scale plantations can have an impact on increasing greenhouse gas emissions, loss of biological biodiversity as well as negative consequences for the local economic conditions, livelihoods and culture of forest dependent people.

Native forests play an important role in preserving indigenous populations, all livelihoods depend on them. Forests are a source of food, building materials, medicines and plants of religious significance, and they are the core of indigenous economies and culture. Replacing tropical rainforests with plantations could threaten the survival of forest-dependent people.

On the one hand, the print media has been hit by environmental issues. On the other hand, the position of the print media industry has also been hit by developments in media technology, particularly the internet. The 
development of new media (internet) and the presence of cyber media are one of the bases for seeing new relationships between media and audiences. So far, traditional media have placed the audience in a passive position, only accepting media exposure, and do not have the freedom to produce information. The audience has even become an object defined by the media as "audience-as-object" (Ang, 1996 in Holmes 2005: 112-113).

In the perspective of cyber culture, the internet is a space where culture is produced, distributed, and consumed. The very nature of this perspective blurs the boundaries of space, geography (places), and demographics (entities). In cyberspace, there is resistance from an established social class structuring, including the relationship between media and audiences that has been understood so far. According to Castells (2004), new media provide different relationships and different meanings to audiences. The media provide symbolic space as a basis for carrying out the process to achieve prosperity, both in terms of the economy and citizenship rights more freely (Cardoso, 2006: 334). It is of course through or chained by technology and information. The position of the audience is no longer separated between being consumers or producers in cyber media. On the internet, audiences can be both consumers and producers, known as prosumer (Cesaero, 2011: 403) or producer (Bruns, 2010).

From the long description above, the theme raised in the study of site specific dance creation is related to the world of the print media industry/especially newspapers. Thus, in addition to exploring the history of paper, paper is a medium as well as Solopos office as a presentation space.

\subsection{Artistic Creations}

The artistic creation stage is the exploration of ideas related to themes and symbols/metaphors that are integrated into the concept of a work. For the creation of site specific dance, explore ideas related to space and values that develop in that space.

The first step is the exploration of the space of light. At the stage of this space experimentation was the making of site specific dance blocks. In addition, the exploration of the medium of newspaper became the main element of body length. For artistic considerations, light exploration was also carried out by experimenting with the dancer's body shadows on the walls and roof. The shadow effect is a form of symbol/metaphor of distorted information in the digital/online era. Information overlaps with each other so that it requires sensitivity and efforts of the communicant to digest and select/sort out the truth of the information that comes.

The second step is exploring the space for movement, blocking and plotting the dancers who will appear. How to use the space and objects in the Solopos lobby can be explored as a supporting element for site specific dance performances, both as artistic material and as a creation setting.

The third step is practice. This was done repeatedly to really recognize the space used for the presentation. The repetition is at the same time to build knowledge so that the body of each dancer is made, so that the body movements become more flexible and flow because the movement does not need to be commanded by the brain anymore.

\subsection{Materialization of work}

There were some blockings in this site specific dance presentation. First is the exploration of the body and newsprint. Where on one side of the space there were thousands of torn pieces of newspaper that suddenly moved. Apparently there were dancers in it. As if, people were very confused and shackled by the information/news around them. Too much information came in causing the person to escape the news that was holding them.

The second blocking is a female dancer with kebaya who is engrossed in responding to the moving rattan installation artwork by attaching a stick with a red heart-shaped tip. The female dancer was very enthusiastic about responding to the rattan installation art in the form of loro blonyo riding the dragon.

The third blocking is a group of male and female dancers who danced using paper masks responding to newspaper and light from the front so that their shadows stuck on the walls of the Solopos lobby.

The fourth blocking is on the second floor, where many male and female dancers were busy reading newspapers and working. It was as if an office containing many employees who were working. Paper sheet tells the story of how the journey of paper in the birth and growth of civilization since ancient times until now in the midst of modernity and the digital era. The dancers described the shift in paper use in the digital age and the social changes that have followed it.

\section{Conclusion}

Site specific dance is a part of contemporary dance that is developing in the academic environment of art. A site specific dance is a dance presentation that requires a special place outside the conventional performing arts in outside of arena/stage. Site specific dance can change the meaning, behavior and feeling of urban space. There was the potential for playfulness, spontaneity, and the absence of the use of standard choreography clashed with the sensuality of urban corners. More and more shows are popping up in skyscrapers, on aisles, on trains, on the 
deck of aircraft carriers, and on a myriad of other unexpected locations around the world.

The success of a site specific dance presentation depends on the relationship between space and the creative process of the performance in the work. What kind of natural relationship between the space/locus, choreographer, performer, appearance/performance with the audience is. Presentation/staging site specific dance requires a special place and space. There is an attachment between space, time and body. Therefore, one aspect of the success of a site specific dance performance is the dancer's knowledge of the relationship between body and space, related to bodily knowledge and intelligence in reading the locus and presentation space.

\section{References}

[1] Bruns, Axel. (2010). News Produsage in a Pro-Am Mediasphere: Why Citizen Journalism Matters, dalam Graham Meikle and Guy Reyden. News Online: Transformations and Continuities. London: Palgrave Macmillan.

[2] Edensor T, C Bowdler, (2015). Site-specific dance: revealing and contesting the ludic qualities, everyday rhythms, and embodied habits of place, Environment and Planning A 2015, volume 47, pages 709-726

[3] Cardoso, Gustavo. (2006). The Media in the Network Society; Browsing, News, Filters, and Citizenship. Lisboa, Portugal: CIES.

[4] Cesaero, Giovanni. (2011). From the "Work of Consumption" to the "Work of Prosummers", dalam Wasko, Janet, Murdock, Graham, and Sousa, Helena (ed.). The Handbook of Political Economy of Communications. West Sussex: Wiley-Blackwell, page 403-435.

[5] Eko Supriyanto, Timbul Haryono, R. M. Soedarsono, Sal Murgiyanto, "Empat Koreografer Tari Kontemporer Indonesia Periode 1990-2008”, dalam jurnal Panggung Vol. 24 No. 4, Desember 2014.

[6] Given, Lisa M. (Ed.). (2008). The SAGE Encyclopedia Qualitative Research Methods, Vol, 1 \& 2. Los Angeles, London, ew Delhi, Singapore: A Sage Reference Publication.

[7] Guntur, 2016, "Penelitian Artistik: Sebuah Paradigma Alternatif", dalam makalah disampaikan dalam Seminar Internasional dengan tema Artistic Research, tanggal 14 Nopember 2016 di Pascasarjana ISI Surakarta.

[8] Hadi, S, 2003, Koreografi Kelompok, Yogyakarta: Elkaphi.

[9]_ 2007, Kajian Tari Teks dan Nonkonteks, Yogyakarta: Pustaka Book Publisher.

[10] Holmes, David. (2005). Communication Theory: Media, Technology and Society. London, Thousand Oaks. New Delhi: SAGE Publications.

[11] Indrayuda, "Fenomena Tari Kontemporer Dalam Karya Tari Mahasiswa Sendratasik UNP dan STSI Padang Panjang", dalam Jurnal Pendidikan dan Kebudayaan, Vol. 16, Nomor 1, Januari 2010.

[12] McCormack D P, 2008, “Geographies for moving bodies: thinking, dancing, spaces" Geography Compass 2 $1822-1836$

[13] Melanie Kloetzel, 2015, "Site Dance: Choreographers and the Lure of Alternative Spaces," dalam academia. edu, downloaded by Isnanta, 2 Oktober 2019 pukul: 23.15 Wib.

[14] Pedgley, Owain. (2007). "Capturing and analysing own design activity". Design Studies, Vol. 28, No. 5 September, pp: 463-483.

[15] R.Aj. Siti Nurchaerani Kusumastuti, 2016, "Perkembangan Koreografi Di Indonesia: Suatu Kajian Karya Tari Kontemporer Di Pusat Kesenian Jakarta-Taman Ismail Marzuki 1968-1987”, dalam desertasi di Fakultas Ilmu Pengetahuan Budaya Program Studi Ilmu Sejarah Universitas Indonesia.

[16] RM. Soedarsono, 2002, Pertunjukan Tari Indonesia di Era Globalisasi. Yogyakarta: Gadjah Mada University Press.

[17] Smith, Hazel and Dean, Roger T. 2009, Practice-led Research, Research-led Practice in the Creative Arts, Edinburgh: Edinburgh University Press Ltd.

[18] Tim Edensor, Caitlan Bowdler, 2015, "Site-specific dance: revealing and contesting the ludic qualities, everyday rhythms, and embodied habits of place," dalam jurnal Environment and Planning, volume 47, pages $709-726$.

[19] Victoria Hunter,2005, Embodying the Site: the Here and Nowin Site-Specific Dance Performance, Cambridge university press. 